\title{
新时期环保政策下的市政工程管理措施分析
}

郝丹

河北通桥市政工程有限公司

DOI:10.32629/ems.v1i1.262

[摘 要] 随着我国环境保护的力度不断加大,相续出台了各项严厉的环境保护政策。市政工程作为一项基础性民生项目,所涉及到的施工 工程众多,应强化对市政工程建设的管理措施,使其能够符合新形势下的环保政策要求。通过不断完善市政工程各项施工工艺,切实保护好 生态环境, 促进社会效益与经济效益的和谐发展。

[关键词] 新时期;环保政策;市政工程;管理措施

\section{1 市政工程施工过程对环境的影响}

1.1 固体废弃物造成的环境污染

市政工程施工过程中会产生大量的固体废弃物, 其中主要包 括了废弃的建筑材料及施工过程中产生的生活垃圾。施工中往往 忽视了对这些物体的及时处理,从而造成了大量堆积。这些杂乱的 废弃物经过长时间放置,会发生理化性质的改变,一些有害元素渗 人到土壤内,影响到附近的土壤安全。并且较难被分解,所产生的影 响甚至会长达百年。废弃物中若含有有害元素,当在一定条件下产 生挥发现象时,会对附近居民造成严重的健康威胁。

1.2 市政工程施工中的噪声污染

噪声污染在市政工程施工过程中较易产生, 应加强对噪声污 染的管控力度。市政工程建设规模较大,会使用到众多不同作用及 规格的机械设备,机械设备在运转过程中所产生的声音较大,对周 边区域造成了严重的噪声污染。其次,市政工程中会较多的利用到 电焊技术,所产生的噪音污染问题较为突出, 应予以高度重视。

1.3 市政工程施工中的大气污染及水污染

由于市政工程施工过程中较易产生粉尘及各种化学物质,如 降尘措施应用不力,会使细小颗粒扩散到空中,经过空气的流动进 而对整体环境造成污染。当空气中弥散着细小颗粒物时,还会导致 空气含氧量下降,进而影响到人们的身体健康。另外,在市政工程建 设过程中还会产生大量废水,如处理不彻底即进行排放,会造成周 边水源的严重污染。

\section{2 新时期环保政策下的市政工程管理措施分析}

2.1 市政工程施工中对固体废弃物的环保处理措施

2.1.1 做好对固体废弃物的调查工作, 认清此物质的材料及来 源,并分析产生此物质的原因,依据调查结果采取相应的管控措施, 从源头控制固体废弃物的产生。固体废弃物主要包括施工过程中 产生的建筑垃圾及施工人员所产生的生活垃圾, 如不注重垃圾分 类,在固体废弃物中往往掺杂着多种废弃物,对后期处理造成了困 难。

2.1.2 应确定固体废弃物的理化性质, 按照危害程度的不同将 其划分为有毒及无毒两大类,并做到分别放置处理。对于无毒的废 弃物判断其二次利用价值, 将具备再次使用条件的废弃物单独放 置,不具备使用条件的废弃物则需要采取严格的销毁措施,通过填 埋及焚烧等方式进行妥善处理。

2.1.3 在市政工程施工过程中, 较多采用的方法为将固体废弃 物运送至专业建筑工程垃圾处理站。在转运建筑垃圾时,首先应就 近选择建筑垃圾处理站,并注意装车完毕后及时覆盖苫布,及时检
查有无纰漏, 做到垃圾转运过程中的安全性, 避免对沿途道路造成 不必要的污染。

2.2 市政工程施工中对噪音污染的环保处理措施

市政工程施工中会应用到较多的大型机械设备, 这些机械设 备在运行时会往往产生较大噪音,进而对周边居民造成严重影响。 在开展市政工程施工前应首先做好机械设备及工具的选择, 依据 施工现场实际需求选择最为合适的施工机械及设备。另外还可在 施工区域设置隔音屏障,经过观察实际使用效果可以看出,隔音屏 障可有效降低施工工具碰撞所产生的噪音。施工单位还要尽量避 免夜间施工,如因工程建设要求不可避免要进行夜间施工,需首先 进行夜间施工报备,并采取合理措施控制噪声强度,将噪声污染降 至最低限度。

2.3 市政工程施工中对大气污染及水污染的环保处理措施

施工扬尘使造成施工大气污染的主要原因, 因重点强化解决 施工过程中的粉尘污染问题。在进行土方开挖施工前,应首先将施 工区域及周边进行围挡,并进行酒水降尘。另外喷雾降尘系统是当 前应用较为广泛的新技术, 喷雾降尘系统是专门针对施工场地而 专业打造的水雾喷淋降尘系统, 采用水射流技术, 经葲体高强度加 压,瞬间释放数以亿计的雾化水颗粒,使雾滴吸附粉尘颗粒,有效抑 制 PM10 或 PM2.5 粉尘,降尘抑尘功效明显。另外要加强对水污染 的控制力度,通过勘察施工现场,并依据实际情况选择合适的水处 理设备,并严格遵守城市污水排放标准,将对环境的影响减至最低 限度。

\section{3 结语}

市政工程是城市建设的基础，环境保护作为市政工程建设中 的重要管理内容,在新时期环保政策下显得愈发突出。在开展市政 工程施工时,应注意加强生态环境的保护工作, 并对施工过程中产 生的污染源进行综合分析, 采用最为稳妥的方式处理好环境污染 问题, 使市政工程施工能够适应新时期环保政策下的全新要求,不 断开创市政建设新篇章。

\section{[参考文献]}

[1]张丽.市政工程施工中的环境保护措施及对策研究 [J].四 川水泥,2018(10):260.

[2]白天宇.市政工程施工中的环境保护管理措施探讨 [J].技 术与市场, 2018(12):221.

[3]靳卫书.探讨市政工程施工中的环境保护措施及对策研究 $[J]$.建筑工程技术与设计,2014(28):135-135. 